\author{
A. Kerimbekov ${ }^{1}$, A.T. Ermekbaeva ${ }^{2}$, E. Seidakmat kyzy ${ }^{1, *}$ \\ ${ }^{1}$ Kyrgyz-Russian Slavic university, Bishkek, Kyrgyzstan; \\ ${ }^{2}$ Osh State university, Kyrgyzstan \\ (E-mail: akl7@rambler.ru, aijana.ermekbaeva@mail.ru, erkeai90@list.ru)
}

\title{
On the solvability of the tracking problem in the optimization of the thermal process by moving point controls
}

\begin{abstract}
In the present article we investigate problems of tracking in the moving point control of thermal processes described by Fredholm integro-differential equations in partial derivatives with the Fredholm integral operator, in the case when the functions of point sources are nonlinear with respect to the control function. It is found that optimal controls are defined as solutions to a system of linear integral equations, and an algorithm for constructing its solution is developed. Sufficient conditions for the unique solvability of the tracking problem are found and an algorithm for constructing a complete solution to the nonlinear optimization problem was indicated.
\end{abstract}

Keywords: generalized solution, Dirac function, functional, tracking problem, optimal control, integral equation, complete solution.

\section{Introduction}

Problems of tracking are an interesting branch of optimal control theory. Control problems, where the process should be controlled so that the deviation of the state of the controlled process differs little from the specified trajectory during the entire control time, are called tracking problems. Such problems are encountered in various branches of science and are of great practical importance. Few works are devoted to the research of tracking problems for optimal control of processes described by integro-differential equations in partial derivatives, in particular with the Fredholm integral operator [1: 55-60; 2]. In the article solvability of the tracking problem is investigated for moving point controls of thermal processes described by integro-differential equations in partial derivatives with the Fredholm integral operator in the case when the functions of point sources are nonlinear in control.

In this article we will use the concept of a generalized solution of a boundary value problem for controlled process, as such approach allows us to adequately describe the actually occurring process. The quality criteria of control is the minimization of the generalized quadratic functional. It is established that optimal controls are defined since solutions of a system of nonlinear integral equations containing unknown functions, both under the integral and outside the integral. An algorithm for constructing a solution to this system was developed and sufficient conditions for its unique solvability were found. A complete solution of the tracking problem is constructed.

\section{Statement of the tracking problem and optimality conditions}

We consider a case when mathematical formalization of the tracking problem for optimal control of the thermal process is reduced to the problem of minimizing the integral generalized quadratic functional

$$
J\left[u_{1}(t), \ldots, u_{m}(t)\right]=\int_{0}^{T} \int_{0}^{1}[V(t, x)-\xi(t, x)]^{2} d x d t+\beta \int_{0}^{T} \sum_{k=1}^{m} p_{k}^{2}\left[u_{k}(t)\right] d t, \quad \beta>0
$$

on the set of solutions of the boundary value problem

$$
V_{t}=V_{x x}+\lambda \int_{0}^{T} K(t, \tau) V(\tau, x) d \tau+\sum_{k=1}^{m} g_{k}(x) \delta\left(x-x_{k}(t)\right) f_{k}\left[u_{k}(t)\right], \quad 0<x<1,0<t \leq T,
$$

\footnotetext{
${ }^{*}$ Corresponding author.

E-mail: erkeai90@list.ru
} 


$$
\begin{gathered}
V(0, x)=\varphi(x), \quad x \in(0,1), \\
V_{x}(t, 0)=0, \quad V_{x}(t, 1)+\alpha V(t, 1)=0, \quad 0<t \leq T, \quad \alpha>0,
\end{gathered}
$$

where $\xi(t, x) \in H\left(Q_{T}\right)$ function describing a given trajectory, $Q_{T}=(0,1) \cdot(0, T), g_{k}(x) \in H(0,1), \quad \varphi(x) \in$ $H_{1}(0,1), \quad K(t, \tau) \in H(D)$ are given functions, $D=\{0 \leq t, \tau \leq T\} ; \delta(x)$ is Dirac Delta function, $x_{k}(t)$ are given functions that describe the laws of motion of the points of application of external forces and take values from $[0,1]$; functions $f_{k}\left[u_{k}(t)\right] \in H(0, T), p_{k}\left[u_{k}(t)\right] \in H(0, T)$ for any controls $u_{k}(t) \in H(0, T)$ and have the property of monotony, i.e.

$$
f_{k u_{k}}\left[u_{k}(t)\right] \neq 0, p_{k u_{k}}\left[u_{k}(t)\right] \neq 0, \quad \forall t \in[0, T] ;
$$

$\lambda$ is a parameter, $T$ is fixed point in time; $H(Y)$ is Hilbert space of quadratically summable functions defined on the set $Y ; H_{1}(Y)$ is Sobolev space of the first order.

Note that according to condition (5) one-to-one correspondences are established between the elements $\left\{u_{1}(t), \ldots, u_{m}(t)\right\} \in H^{m}(0, T)=H(0, T) \times \ldots \times H(0, T)$ of the control space and the elements $V(t, x)$ of the state controlling process $\{V(t, x)\}$ space.

Given this commitment, we calculate the increments of the functional (1). By direct calculation we have the equality

$$
\begin{gathered}
\Delta I\left[u_{1}(t), \ldots, u_{m}(t)\right]=I\left[u_{1}(t)+\Delta u_{1}(t), \ldots, u_{m}(t)+\Delta u_{m}(t)\right]-I\left[u_{1}(t), \ldots, u_{m}(t)\right]= \\
=-\int_{0}^{T} \Delta \Pi\left[t, V(t, x), \omega(t, x), u_{1}(t), \ldots, u_{m}(t)\right] d t+\int_{0}^{T} \int_{0}^{1} \Delta V^{2}(t, x) d x d t
\end{gathered}
$$

where

$$
\begin{gathered}
\Delta \Pi\left[t, V(t, x), \omega(t, x), u_{1}(t), \ldots, u_{m}(t)\right]= \\
=\Pi\left[t, V(t, x), \omega(t, x), u_{1}(t)+\Delta u_{1}(t), \ldots, u_{m}(t)+\Delta u_{m}(t)\right]-\Pi\left[t, V(t, x), \omega(t, x), u_{1}(t), \ldots, u_{m}(t)\right], \\
\Pi\left[t, V(t, x), \omega(t, x), u_{1}(t), \ldots, u_{m}(t)\right]=\sum_{k=1}^{m}\left\{g_{k}\left[x_{k}(t)\right] \omega\left[t, x_{k}(t)\right] f_{k}\left[u_{k}(t)\right]-\beta p_{k}^{2}\left[u_{k}(t)\right]\right\},
\end{gathered}
$$

function $\omega(t, x)$ is a generalized solution to a boundary value problem

$$
\begin{gathered}
\omega_{t}+\omega_{x x}=-\lambda \int_{0}^{T} K(\tau, t) \omega(\tau, x) d \tau+2[V(t, x)-\xi(t, x)], \quad 0<x<1,0 \leq t<T, \\
\omega(T, x)=0, \quad 0<x<1, \\
\omega_{x}(t, 0)=0, \quad \omega_{x}(t, 1)+\alpha \omega(t, 1)=0, \quad 0 \leq t<T,
\end{gathered}
$$

$V(t, x)$ is a generalized solution to the main boundary value problem (2-5). The problem (8) is called a conjugate boundary value problem.

From (6) and (7) it follows that $\Delta I\left[u_{1}(t), \ldots, u_{m}(t)\right] \geq 0$ on the controls satisfying the condition $\Delta \Pi[t, V(t, x)$, $\left.\omega(t, x), u_{1}(t), \ldots, u_{m}(t)\right] \leq 0$. These relations are at the basis of maximum principle for the considered problem of optimal control, i.e., on controls, where the function $\Pi(\cdot)$ reaches its maximum, and $I\left[u_{1}(t), \ldots, u_{m}(t)\right]$ reaches its minimum.

We investigate the function $\Pi\left[t, V(t, x), \omega(t, x), u_{1}(t), \ldots, u_{m}(t)\right]$ for the maximum. For each fixed $t \in[0, T]$ and $x \in(0,1)$ it turns into a function of $m$ variables $\left\{u_{1}, \ldots, u_{m}\right\} \in R^{m}-m$ dimensional Euclidean space.

Consider the case when the set of admissible values of variables $u_{1}, \ldots, u_{m}$ are open sets. Then, by applying the classical method of research for the extremum, we obtain the following relations

$$
\Pi_{u_{k}}\left[\cdot, u_{1}(t), \ldots, u_{m}(t)\right]=g_{k}\left[x_{k}(t)\right] \omega\left[t, x_{k}(t)\right] f_{k u_{k}}\left[u_{k}(t)\right]-2 \beta p_{k}\left[u_{k}(t)\right] p_{k u_{k}}\left[u_{k}(t)\right]=0,
$$

$k=1,2, \ldots, m$, a necessary condition of the extremum of the first order [3: 379-380].

From this we obtain the necessary first-order optimality condition

$$
2 \beta \frac{p_{k}\left[u_{k}(t)\right] p_{k u_{k}}\left[u_{k}(t)\right]}{f_{k u_{k}}\left[u_{k}(t)\right]}=g_{k}\left[x_{k}(t)\right] \omega\left[t, x_{k}(t)\right], \quad k=1,2, \ldots, m,
$$

that is valid for almost all $t \in[0, T]$. 
The Hess matrix for the function $\Pi\left(\cdot, u_{1}, \ldots, u_{m}\right)$ has the form

$$
\Gamma\left[\Pi\left(\cdot, u_{1}, \ldots, u_{m}\right)\right]=\operatorname{diag}\left\{g_{k}\left[x_{k}(t)\right] \omega\left[t, x_{k}(t)\right] f_{k u_{k} u_{k}}\left[u_{k}(t)\right]-2 \beta\left(p_{k}\left[u_{k}(t)\right] p_{k u_{k}}\left[u_{k}(t)\right]\right)_{u_{k}}\right\} .
$$

Then the necessary second-order optimality condition for the maximum, according to Sylvester's criterion, has the form of the inequality [3: 379-380]

$$
(-1)^{j} \prod_{k=1}^{j} f_{k u_{k}}\left[u_{k}(t)\right]\left(\frac{p_{k}\left[u_{k}(t)\right] p_{k u_{k}}\left[u_{k}(t)\right]}{f_{k u_{k}}\left[u_{k}(t)\right]}\right)_{u_{k}}>0, \quad j=1,2, \ldots, m
$$

which was obtained taking into account of the condition (9) and it is for almost all $t \in[0, T]$.

Relations (9) and (12), which are realized almost at all $t \in[0, T]$ are called optimality conditions.

Since the remainder $\int_{0}^{T} \int_{0}^{1} \Delta V^{2}(t, x) d x d t$ in relation (6) takes on a sufficiently small value, the condition $\Delta \Pi[\cdot, u] \leq 0$ is both necessary and sufficient for the optimality controls $u_{1}, \ldots, u_{m}$.

To determine the optimal controls $u_{1}^{0}(t), \ldots, u_{m}^{0}(t)$ it is necessary to use the first order optimality condition of equality (9). For this purpose we use generalized solutions of both the main and adjoint boundary value problems.

\section{Generalized solutions of the main and conjugated boundary value problems of a controlled process}

The generalized solution to the boundary value problem (2)-(5) has the form [4]

$$
\begin{gathered}
V(t, x)=\sum_{n=1}^{\infty} V_{n}(t) z_{n}(x) \\
=\sum_{n=1}^{\infty}\left(\lambda \int_{0}^{T} R_{n}(t, s, \lambda) a_{n}(s) d s+a_{n}(t)\right) z_{n}(x),
\end{gathered}
$$

where $R_{n}(t, s, \lambda)$ is the resolvent [5: 98-101] of the kernel $\left.K_{n}(t, s)=\int_{0}^{t} e^{-\lambda_{n}^{2}(t-\tau}\right) K(\tau, s) d \tau$,

$$
\left.a_{n}(t)=e^{-\lambda_{n}^{2} t} \varphi_{n}+\int_{0}^{t} e^{-\lambda_{n}^{2}(t-\tau}\right) \sum_{k=1}^{m} g_{k}\left[x_{k}(\tau)\right] z_{n}\left[x_{k}(\tau)\right] f_{k}\left[u_{k}(\tau)\right] d \tau .
$$

The solution of the conjugate boundary value problem has the form

$$
\omega(t, x)=\sum_{n=1}^{\infty}\left(\lambda \int_{0}^{T} B_{n}(\tau, t, \lambda) q_{n}(\tau) d \tau+q_{n}(t)\right) z_{n}(x),
$$

where $B_{n}(\tau, t, \lambda)$ is the resolvent [5; 98-101] of the kernel $G_{n}(\tau, t)=\int_{t}^{T} e^{-\lambda_{n}^{2}(s-t)} K(\tau, s) d s$,

$$
q_{n}(t)=-2 \int_{t}^{T} e^{-\lambda_{n}^{2}(s-t)}\left[V_{n}(s)-\xi_{n}(s)\right] d s,
$$

where $V_{n}(t)$ and $\xi_{n}(t)$ are the Fourier coefficients of the functions $V(t, x)$ and $\xi(t, x)$, respectively.

\section{System of nonlinear integral equations of optimal controls}

The desired controls $\left\{u_{1}^{0}(t), \ldots, u_{m}^{0}(t)\right\}$ we find are according to the optimality conditions (9) and (10). Note that the optimality condition (10) restrict the functions class $\left\{f_{k}\left[u_{k}(t)\right], p_{k}\left[u_{k}(t)\right]\right\}$. We assume that the functions $\left\{f_{k}\left[u_{k}(t)\right], p_{k}\left[u_{k}(t)\right]\right\}$ satisfy the condition (10). Then the controls $\left\{u_{1}^{0}(t), \ldots, u_{m}^{0}(t)\right\}$ defined by the condition (11) will be the desired optimal controls. In the formula (9) we replace the function $\omega(t, x)$ according to the formulas (12), (13) and obtain a system of equalities

$$
2 \beta \frac{p_{k}\left[u_{k}(t)\right] p_{k u_{k}}\left[u_{k}(t)\right]}{f_{k u_{k}}\left[u_{k}(t)\right]}=g_{k}\left[x_{k}(t)\right] \sum_{n=1}^{\infty}\left(\lambda \int_{0}^{T} B_{n}(s, t, \lambda) q_{n}(s) d s+q_{n}(t)\right) z_{n}\left[x_{k}(t)\right],
$$

$k=1,2, \ldots, m$. 
Now we transform this system of integral equations (14) to the form

$$
\begin{gathered}
\beta \frac{p_{k}\left[u_{k}(t)\right] p_{k u_{k}}\left[u_{k}(t)\right]}{f_{k u_{k}}\left[u_{k}(t)\right]} \\
=g_{k}\left[x_{k}(t)\right] \sum_{n=1}^{\infty} z_{n}\left[x_{k}(t)\right] h_{n}(t, \lambda)-g_{k}\left[x_{k}(t)\right] \sum_{n=1}^{\infty} z_{n}\left[x_{k}(t)\right] \int_{0}^{T} W_{n}(t, \eta, \lambda) \sum_{j=1}^{m} q_{j}\left[x_{j}(\eta)\right] d \eta,
\end{gathered}
$$

$k=1,2, \ldots, m$, where

$$
\begin{gathered}
W_{n}(t, \eta, \lambda)=\int_{0}^{T} \epsilon_{n}(y, t, \lambda) Y_{n}(y, \eta, \lambda) d y, \\
\epsilon_{n}(t, \tau, \lambda)= \begin{cases}\lambda \int_{0}^{y} B_{n}(s, t, \lambda) e^{-\lambda_{n}^{2}(y-s)} d s, \quad 0 \leq y \leq t, \\
e^{-\lambda_{n}^{2}(y-s)}+\lambda \int_{0}^{y} B_{n}(s, t, \lambda) e^{-\lambda_{n}^{2}(y-s)} d s, \quad t \leq y \leq T ;\end{cases} \\
Y_{n}(y, \eta, \lambda)= \begin{cases}e^{-\lambda_{n}^{2}(y-\eta)}+\lambda \int_{\eta}^{T} R_{n}(y, \tau, \lambda) e^{-\lambda_{n}^{2}(\tau-\eta)} d \tau, \quad 0 \leq \eta \leq y, \\
\lambda \int_{\eta}^{T} R_{n}(y, \tau, \lambda) e^{-\lambda_{n}^{2}(\tau-\eta)} d \tau, \quad y \leq \eta \leq T .\end{cases}
\end{gathered}
$$

Next, we investigate the unique solvability of the nonlinear integral equations system (15). This system nonlinearly contains unknown functions $u_{1}(t), \ldots, u_{m}(t)$ under the integral and outside the integral.

Suppose

$$
\beta \frac{p_{k}\left[u_{k}(t)\right] p_{k u_{k}}\left[u_{k}(t)\right]}{f_{k u_{k}}\left[u_{k}(t)\right]}=\sigma_{k}(t), \quad k=1,2, \ldots, m .
$$

Then, according to the condition (10) there is a function $\psi[\cdot]$ such that

$$
u_{k}(t)=\psi_{k}\left[t, \sigma_{k}(t), \beta\right], \quad k=1,2, \ldots, m .
$$

Taking into account (16) and (17), we rewrite the system (15) in the form

$$
\begin{gathered}
\sigma_{k}(t)=\sum_{n=1}^{\infty} \theta_{k n}\left[x_{k}(t)\right]\left(h_{n}(t, \lambda)\right. \\
\left.-\int_{0}^{T} W_{n}(t, \eta, \lambda) \sum_{j=1}^{m} \theta_{j n}\left[x_{j}(\eta)\right] f_{j}\left(\psi_{j}\left[\eta, \sigma_{j}(\eta), \beta\right]\right) d \eta\right), \quad k=\overline{1, m}
\end{gathered}
$$

where

$$
\theta_{k n}\left[x_{k}(t)\right]=g_{k}\left[x_{k}(t)\right] z_{n}\left[x_{k}(t)\right], \quad k=1,2, \ldots, m .
$$

Now, we compose the vector-functions

$$
\begin{gathered}
\sigma(t)=\left\{\sigma_{1}(t), \ldots, \sigma_{m}(t)\right\}, \overline{\theta_{n}}[t]=\left\{\theta_{1 n}\left[x_{1}(t)\right], \ldots, \theta_{m n}\left[x_{m}(t)\right]\right\}, \\
\psi[t, \sigma(t), \beta]=\left\{\psi_{1}\left[t, \sigma_{1}(t), \beta\right], \ldots, \psi_{m}\left[t, \sigma_{m}(t), \beta\right]\right\}, \\
f(\psi[t, \sigma(t), \beta])=\left\{f_{1}\left(\psi_{1}\left[t, \sigma_{1}(t), \beta\right]\right), \ldots, f_{m}\left(\psi_{m}\left[t, \sigma_{m}(t), \beta\right]\right)\right\}
\end{gathered}
$$

and rewrite the system of equalities (18) in the vector form

$$
\sigma(t)=\sum_{n=1}^{\infty} \tilde{\theta_{n}}(t)\left(h_{n}(t, \lambda)-\int_{0}^{T} W_{n}(t, \eta, \lambda) \tilde{\theta}_{n}^{*}(\eta) f(\psi[\eta, \sigma(\eta), \beta]) d \eta\right),
$$

where $\sigma(t), \tilde{\theta_{n}}(t), \quad f(\psi[\eta, \sigma(\eta), \beta])$ are the column vectors, symbol $*$ is a transposition sign.

Further, the following lemmas are proved by direct calculations. 
Lemma 1. Vector function

$$
h(t, \lambda)=\left\{h^{(1)}(t, \lambda), \ldots, h^{(m)}(t, \lambda)\right\}=\sum_{n=1}^{\infty} \tilde{\theta_{n}}(t) h_{n}(t, \lambda)
$$

is an element of space $H^{m}(0, T)$, i.e., $h^{(k)}(t, \lambda) \in H(0, T)$ for each $k=1,2, \ldots, m$.

Lemma 2. Vector function

$$
W[\sigma(t)]=\left\{W_{1}[\sigma(t)], \ldots, W_{m}[\sigma(t)]\right\},
$$

where

$$
\begin{gathered}
W_{k}[\sigma(t)]=\sum_{n=1}^{\infty} \theta_{n k}(t) \int_{0}^{T} W_{n}(t, \eta, \lambda){\tilde{\theta_{n}}}^{*}(\eta) f(\psi[\eta, \sigma(\eta), \beta]) d \eta \\
=\sum_{n=1}^{\infty} g_{k}\left[x_{k}(t)\right] z_{n}\left[x_{k}(t)\right] \int_{0}^{T} W_{n}(t, \eta, \lambda) \sum_{j=1}^{m} g_{j}\left[x_{j}(t)\right] z_{n}\left[x_{j}(t)\right] f_{j}\left(\psi_{j}\left[\eta, \sigma_{j}(\eta), \beta\right]\right) d \eta
\end{gathered}
$$

is an element of space $H^{m}(0, T)$, i.e., $W_{k}[\sigma(t)] \in H(0, T), \quad k=1,2, \ldots, m$.

According to Lemmas 1 and 2, equation (19) is considered in space $H^{m}(0, T)$. Taking into account formulas (20) and (21) system of integral equations (19) is rewritten in operator form as

$$
\sigma=W[\sigma]+h
$$

Lemma 3. Let the functions $f_{k}\left[u_{k}(t)\right]$ and $\psi_{k}\left[t, \sigma_{k}(t), \beta\right]$ satisfy the Lipschitz condition with respect to the functional variable, i.e.

$$
\begin{gathered}
\left\|f_{k}\left[u_{k}(t)\right]-f_{k}\left[\tilde{u_{k}}(t)\right]\right\|_{H(0, T)} \leq f_{k}^{0}\left\|u_{k}(t)-\tilde{u_{k}}(t)\right\|_{H(0, T)}, \quad f_{k}^{0}>0, \quad k=1,2, \ldots, m, \\
\left\|\psi_{k}\left[t, \sigma_{k}(t), \beta\right]-\psi_{k}\left[t, \tilde{\sigma_{k}}(t), \beta\right]\right\|_{H(0, T)} \leq \psi_{k}^{0}(\beta)\left\|\sigma_{k}(t)-\tilde{\sigma_{k}}(t)\right\|_{H(0, T)}, \quad \psi_{k}^{0}(\beta)>0, \quad k=1,2, \ldots, m .
\end{gathered}
$$

Then, under the condition

$$
\begin{gathered}
\gamma=T\left(g_{k}^{0}\right)^{2}\left(\frac{1}{\lambda_{1}^{0}}+\frac{1}{6}\right)\left(1+\frac{\lambda^{2} k_{0} T}{\left(\sqrt{2} \lambda_{1}-|\lambda| \sqrt{k_{0} T}\right)^{2}}\right) \sqrt{m} f^{0} \psi^{0}(\beta)<1, \\
f^{0}=\max \left\{f_{1}^{0}, \ldots, f_{m}^{0}\right\}, \quad \psi^{0}=\max \left\{\psi_{1}^{0}, \ldots, \psi_{m}^{0}\right\}
\end{gathered}
$$

where the operator $W[\sigma]: H^{m}(0, T) \rightarrow H^{m}(0, T)$ is contracting.

Theorem 1. Let conditions (22), (23), and (24) be satisfied. Then the operator equation (19) in space $H^{m}(0, T)$ has a unique solution.

Proof. Since the Hilbert space $H^{m}(0, T)$ is complete [6: 44-45], the operator $W[\cdot]$ transforms the space $H^{m}(0, T)$ into itself and becomes contracting, then according to the principle of contracting operators, the operator $W[\cdot]$ has a unique fixed point $\sigma^{0}(t)$.

This solution is defined as the limit of a sequence $\sigma^{(n)}(t)$, i.e., is determined by the successive approximation method

$$
\sigma^{(n)}(t)=W\left[\sigma^{(n-1)}\right]+h(t, \lambda), \quad n=1,2,3, \ldots,
$$

where the initial guess $\sigma^{(0)}(t)$ is chosen arbitrarily, in particular $\sigma^{(0)}(t)=h(t, \lambda)$. Then, as is known, the estimate

$$
\left\|\tilde{\sigma}(t)-\sigma^{(n)}(t)\right\|_{H^{m}(0, T)} \leq \frac{\left(2 f^{0} \psi^{0}(\beta)\right)^{n}}{1-2 f^{0} \psi^{0}(\beta)}\left\|W\left[\sigma^{(0)}(t)\right]\right\|_{H^{m}(0, T)}
$$

is valid.

Thus, substituting the obtained solution $\tilde{\sigma}(t)=\left\{\tilde{\sigma_{1}}(t), \ldots, \tilde{\sigma_{m}}(t)\right\}$ into $(16)$, we find the desired optimal controls

$$
u_{k}^{0}(t)=\psi_{k}\left[t, \tilde{\sigma_{k}}(t), \beta\right], \quad k=1,2, \ldots, m .
$$

The solution of boundary value problem (2)-(5) corresponding to these controls, according to (11) is determined by the formula

$$
V^{0}(t, x)=\sum_{n=1}^{\infty}\left(\lambda \int_{0}^{T} R_{n}(t, s, \lambda) a_{n}^{0}(s) d s+a_{n}^{0}(t)\right) z_{n}(x)
$$


where

$$
\left.a_{n}^{0}(t)=e^{-\lambda_{n}^{2} t} \psi_{n}+\int_{0}^{t} e^{-\lambda_{n}^{2}(t-\tau}\right) \sum_{k=1}^{m} g_{k}\left[x_{k}(\tau)\right] z_{n}\left[x_{k}(\tau)\right] f_{k}\left[u_{k}^{0}(\tau)\right]
$$

Using the found $u_{k}^{0}(t), \quad k=1, \ldots, m$ and $V^{0}(t, x)$ we calculate the minimum value of the functional (1)

$$
J\left[u_{1}^{0}(t), \ldots, u_{m}^{0}(t)\right]=\int_{0}^{T} \int_{0}^{1}\left[V^{0}(t, x)-\xi(t, x)\right]^{2} d x d t+\beta \int_{0}^{T} \sum_{k=1}^{m} p_{k}^{2}\left[u_{k}^{0}(t)\right] d t .
$$

Thus the triple found

$$
\left\{\left(u_{1}^{0}(t), \ldots, u_{m}^{0}(t)\right), \quad V^{0}(t, x), \quad J\left[u_{1}^{0}(t), \ldots, u_{m}^{0}(t)\right]\right\}
$$

is a complete solution to the tracking problem with nonlinear optimal control of the heat propagation process under the action of moving point sources.

\section{Conclusion}

In conclusion, we note some features of the investigated tracking problem for optimal point control of thermal processes described by integro-differential equations in partial derivatives.

The presence of the integral operator has led to the need in study of the Neumann series that appear when determining the Fourier coefficients of the boundary value problem. It was found that the convergence radius of the Neumann series with respect to the parameter $\lambda$ expands with increasing number of the Fourier coefficient. The optimization problem can be solved only with a radius of convergence corresponding to the first Fourier coefficient.

A method for solving a system of nonlinear integral equations of a non-standard form has been developed. Such the system of equations appears in the case when the functions of external influences are nonlinear with respect to the control.

Using the property of the Dirac $\delta$ function, an algorithm has been developed for constructing a complete solution to the tracking problem using the example of controlling thermal processes, which can be used in solving and qualitative research of the problems of programmed control of various technological processes, described by functional equations of a more complex nature.

\section{References}

1 Керимбеков А. Нелинейное оптимальное управление колебаниями в линиях передач / А. Керимбеков. - Бишкек: Изд-во КРСУ, 2008. - 132 с.

2 Kerimbekov A. Generalized solution of a boundary value problem under point exposure of external / A. Kerimbekov, E. Abdyldaeva, U. Duishenalieva // Journal Pure Applied Mathematics. - 2017. - 113. - No. 4. - P. 609-623.

3 Смирнов В.И. Курс высшей математики / В.И. Смирнов. - М.: Наука, 1974. - 480 с.

4 Kerimbekov A. Numerical Analysis of the Influence of the Initial Parameters on the Convergence Rate of the Approximate Solution of the Boundary Value Problem/ A. Kerimbekov, A. Ermekbaeva, G. Mombekova // AIP Conference Proceedings. - 2019. - 2183. - 070024. - P. 1-5.

5 Краснов М.В. Интегральные уравнения / М.В. Краснов. - М.: Наука, 1975. - 304 с.

6 Люстерник Л.А. Элементы функционального анализа / Л.А. Люстерник, В.И. Соболев. - М.: Наука, 1965. - 520 с. 


\author{
А. Керімбеков ${ }^{1}$, А.Т. Ермекбаева ${ }^{2}$, Е. Сейдакмат қызы ${ }^{1}$ \\ ${ }^{1}$ Б.Н. Елъцин атындавы Қырзыз-Ресей Славян университеті, Бішкек, Қырғызстан; \\ ${ }^{2}$ Ош мемлекеттік университеті, Қырәызстан
}

\title{
Жылу процестерін қозғалмалы нүктелік басқару кезіндегі бақылау есебінің шешілімділігі жөнінде
}

\begin{abstract}
Мақалада нүктелік көздер функциялары басқару функцияларына қатысты сызықтыемес болған жағдайда Фредгольм интегралдық операторлы дербес туындылы фредгольмдік интегралдықдифференциалдық теңдеулермен сипатталатын жылу процестерін қозғалмалы нүктелік басқару кезіндегі қадағалау есебінің шешілімділігі зерттелген. Оптималды басқару сызықты интегралдық теңдеулер жүйесінің шешімі ретінде анықталды және шешімді тұрғызу алгоритмі құрылды. Қадағалау есебінің бірмәнді шешілуінің жеткілікті шарты табылды және сызықтыемес оңтайландыру есептерінің шешімін тұрғызудың толық алгоритмі көрсетілді.
\end{abstract}

Kiлm сөздер: жалпыланған шешім, Дирак функциясы, функционал, қадағалау есебі, оптималды басқару, интегралдық теңдеу, толық шешім.

\author{
А.Керимбеков ${ }^{1}$, А.Т. Эрмекбаева ${ }^{2}$, Э. Сейдакмат кызы ${ }^{1}$ \\ ${ }^{1}$ Кыргызско-Российский Славянский университет им. Б.Н. Елъцина, Бишкек, Кыргызстан; \\ ${ }^{2}$ Ошский государственный университет, Кыргызстан
}

\section{О разрешимости задачи слежения при подвижном точечном управлении тепловыми процессами}

В статье исследована разрешимость задачи слежения при подвижных точечных управлениях тепловыми процессами, описываемыми фредгольмовыми интегро-дифференциальными уравнениями в частных производных с интегральным оператором Фредгольма, в случае когда функции точечных источников нелинейны относительно функции управления. Установлено, что оптимальные управления определены как решения системы линейных интегральных уравнений, и разработан алгоритм построения ее решения. Найдены достаточные условия однозначной разрешимости задачи слежения, и указан алгоритм построения полного решения задачи нелинейной оптимизации.

Ключевые слова: обобщенное решение, функция Дирака, функционал, задача слежения, оптимальное управление, интегральное уравнение, полное решение.

\section{References}

1 Kerimbekov, A. (2008). Nelineinoe optimalnoe upravlenie kolebaniiami v liniiakh peredach [Nonlinear optimal control of oscillations in transmission lines]. Bishkek: Publishing house of KRSU [in Russian].

2 Kerimbekov, A., Abdyldaeva, E., \& Duishenalieva, U. (2017). Generalized solution of a boundary value problem under point exposure of external. Journal Pure Applied Mathematics, 113(4), 609-623.

3 Smirnov, V.I. (1974). Kurs vysshei matematiki [Higher Mathematics Course]. Moscow: Nauka [in Russian].

4 Kerimbekov, A., Ermekbaeva, A., \& Mombekova, G. (2019). Numerical analysis of the influence of the initial parameters on the convergence rate of the approximate solution of the boundary value problem. AIP Conference Proceedings, $2183(070024), 1-5$.

5 Krasnov, M.V. (1975). Integralnye uravneniia [Integral equations]. Moscow: Nauka [in Russian].

6 Lyusternik, L.A., \& Sobolev, V.I. (1965). Yelementy funktsionalnogo analiza [Elements of functional analysis]. Moscow: Nauka [in Russian]. 